\title{
URGENSI PENDIDIKAN DEMOKRASI DAN MULTIKULTURAL BAGI MASYARAKAT PLURAL
}

\author{
Andika Apriawan ${ }^{1}$ Dewi Puspita Ningsih ${ }^{2}$ \\ andika.apriawan@gmail.com ${ }^{1}$ dewining66@gmail.com ${ }^{2}$
}

\begin{abstract}
Abstrak. Pendidikan demokrasi dan multikultural adalah upaya penanaman dan penumbuhan pemahaman serta kesadaran berfikir obyektif dari masyarakat dalam melihat realitas kehidupan sosial yang plural. Pluralitas sangat nampak dalam kehidupan masyarakat Indonesia yang dengannya menjadikan upaya penananam dan penumbuhan pemahaman demokrasi dan multikultural menjadi penting. Pentingnya pendidikan ini akan menghindari masyarakat dari resiko pertikaian bahkan berakibat disintegratif. Resiko sosial yang sering dialami masyarakat yang plural yaitu kerapnya terjadi konflik destruktif yang mengatasnamakan kepentingan kelompok-kelompok sosial. Hal-hal lain juga yang dapat dirasakan dengan adanya pemikiran pendidikan demokrasi dan multikultural yaitu masyarakat mengetahui bahaya konflik horizontal yang kadangkala itu dapat diakibatkan oleh redahnya pemahaman dan kesadara masyarakat terhadap realitas sosial.
\end{abstract}

Keyword: Demokrasi, Multikultural, Plural, Konflik Destruktif

\section{PENDAHULUAN}

Indonesia merupakan negara yang dikenal dengan masyarakatnya yang majemuk, hidup dengan penuh prbedaan yang bisa saja berpotensi menimbulkan konflik horizontal. Hal itu berarti konflik bisa saja terjadi di antara individu atau kelompok masyarakat yang memiliki status sosial budaya dan agama yang berbeda. Pada dasarnya kehidupan sosial yang penuh dengan perbedaan merupakan keniscayaan yang membawa keindahan tersendiri bila itu dapat dirawat dan dipelihara dengan baik yang dipenuhi dengan benih-benih kesadaran kolektif. Karena suatu bangsa akan besar apabila bangsa tersebut mampu membangun kesadaran dan hidup bersama di dalamnya yang senantiasa mengalami perbedaan dalam kesamaan (to experienced difference in equality) serta bersedia bekerjasama untuk kehidupan bersama.

Kendati pun demikian, ada masa-masa yang mengkhawatirkan sehingga menjadi bahan renungan dan perhatian yang lebih bagi siapa saja sebagai bentuk konsekuensi hidup yang pluralis-multikulturalis. Faktanya setiap tiba musim politik masyarakat tidak kekurangan pengalaman mengahadapi tantangan hidup begitu berat yang selalu bergejolak dengan isu- isu SARA yang bertebaran baik kehidupan di dunia nyata lebih-lebih di dunia maya.

Dalam suatu masyarakat sosial pasti akan menemukan banyak kelompok masyarakat yang memiliki karakteristik berbeda-beda. Perbedaan-perbedaan karakteristik tersebut berkenaan dengan tingkat diferensiasi dan stratifikasi sosial. Masyarakat sosial yang seperti itu disebut juga masyarakat multikultural. Kondisi masyarakat multikultural ternyata tidak selamanya kondusif bagi pengembangan demokrasi.

Transformasi sosial budaya mengandung arti proses perubahan atau pembaharuan struktur sosial, sedangkan dipihak lain mengandung makna proses perubahan atau pembaharuan nilai

Setiap masyarakat senantiasa mempunyai penghargaan terhadap hal-hal tertentu dalam masyarakat yang bersangkutan. Kalau suatu masyarakat lebih menghargai kekayaan materiil dari pada kehormatan, misalnya mereka lebih banyak mempunyai kekayaan materi yang akan memempati kedudukan yang lebih tinggi apabila di bandingkan dengan pihak-pihak lain. Gejala tersebut menimbulkan lapisan masyarakat, yang merupakan pembedaan posisi seseorang atau 
kelompok dalam kedudukan yang berbeda-beda secara vertical.

Para elit politik dan agama atau pakar ilmu sosial telah menganalisis akar persoalan konflik cenderaung menjadikan kesenjangan sosial sebagai kambing hitam. Amat sedikit yang mau mengakui kalau persoalan konflik dan kekerasan terkait erat dengan praktik pengajaran (pendidikkan) agama, dan moral yang belum memupuk kerukunan bersama.

Kehidupan sosial budaya yang beranekaragam bila tidak diatasi dalam kancah dunia pendidikan akan berakibat sangat buruk bagi system di masyarakat. Hakikatnya dengan pendidikan di harapkan akam membentuk masyarakan madani civic sosiety yang dapat menerima ragam kehidupan sosial dan budaya untuk mengurangi dampak permaslahan yang akan terjadi dalam masyarakat.

Seperti kita ketahui, masyarakat saat ini sepertinya telah kehilangan karakter yang telah dibangun berabad-abad. Keramahan, tenggangrasa, kesopanan, rendah hati, suka menolong, solidaritas sosial dan sebagainya yang merupakan jati diri bangsa seolah-olah hilang begitu saja. Fenomena merosotnya kualitas moral bangsa Indonesia tampaknya telah membuka kesadaran bersama perlunya memperkuat moralitas bangsa. Bangsa Indonesia yang bersifat multikultur hingga kini masih dibayangi oleh aneka macam konflik. Untuk mengantisifikasinya tentu saja membutuhkan sebuah paradigm pendidikan yang melembagakan sifat pluralisme budaya dalam system pendidikan dengan mengedepankan prinsip persamaan saling menghargai menerima dan memahami serta danya komitmen moral terhadap keadilan social PEMBAHASAN

\section{A. Multukultural}

Multikultural merupakan suatu istilah untuk menyebut sutau bangsa atau Negara yang masyarakatnya majemuk. Multikultural berasal dari kata multi yang berarti plural dan kultur yang berarti budaya. Menurut Tilaar istilah plural mengandung arti yang berjenis-jenis, karena pluralism bukan berarti sekedar pengakuan akan adanya hal-hal yang berjenisjenis tetapi juga pengakuan itu memiliki implikasi-implikasi politis, sosial dan ekonomi. Sedangkan Choirul Mahfud mengatakan secara hakiki, dalam kata itu terkandung pengakuan akan martabat manusia yang hidup dalam komunitasnya dengan kebudayaannya masingmasing yang unik.

Dengan multikulturalisme menumbuhkan kesadaran berfikir obyektif dari masyarakat dalam melihat seseorang dengan segala macam status sosial dan perbedaan kelas (stratifiksi sosial) yang melekat pada dirinya. Kekayaan atau keningratan adalah bukan ukuran satusatunya bagi seseorang untuk mendapatkan penghormatan, penghargaan, dan prestise (status sosial yang tinggi) dalam kehidupan masyarakat. Masyarakat akan lebih melihat kepribadian, kemampuan dan tanggung jawab sosial yang positif yang ada pada seseorang terhadap diri sendiri, keluarga maupun lingkungan disekitarnya.

Selain itu dengan multikulturalisme seseorang diharapkan bisa beranggapan bahwa tidak semua orang kaya dan orang berstatus sosial tinggi mempunyai kekuatan mempengaruhi orang lain untuk melakukan sesuatu. Namun demikian, orang yang mempunyai status dan posisi kelas sosial yang tinggi mempunyai kesempatan yang lebih besar untuk mempengaruhi orang lain.

\section{B. Multikultural pada aspek sosial}

Manusia adalah individu perwakilan dari seluruh manusia atau masyarakat. Ia sama dengan semua manusia lain, namun sekaligus ia berbeda. Hal itu terkait dengan pemahaman multikultur dan pluralitas sebagai realitas yang muncul dalam semua unsur lapisan masyarakat. Keterkaitannya dengan realitas multikultur dalam masyarakat sosial adalah bahwa manusia lah, sebagai individu diri, merupakan aspek terkecil yang membangun realitas multikultur tersebut. Manusia memiliki sifat, mereka mempunyai struktur fisik dan mental. Mereka membawa personalitas mereka tersendiri, yang terdiri atas watak dan temperamen. Personalitas 
atau kepribadian itu sendiri memahami manusia adalah serupa karena sama menanggung situasi kemanusiaan dan dikotomi eksistensial inherennya, mereka unik dalam caranya yang spesifik memecahkan masalah kemanusiaannya sendiri.

Manusia secara inheren memiliki hasrat dan keinginan, serta kepentingan. Kepentingan disebut negatif (negative interest) pada saat kepentingan diupayakan tercapai dengan mengabaikan hak orang lain, nilai persamaan, keadilan dan persaudaraan. Negative interest inilah yang pada titik akumulasi tertentu dapat menyebabkan konflik individual atau kelompok. Dorongan tersebut dalam istilah Fromm disebut tingkat kedestruktifan, yang dipengaruhi oleh tingkat kedestruktifan masingmasing individu yang bersifat bawaan, faktorfaktor psikis, dan juga perkembangan peradaban. Dorongan destruktif jahat lebih jauh lagi Fromm mengatakan bahwa dikontol oleh hasrat manusia akan pemenuhan kebutuhan eksistensial mereka, sementara hasrat tersebut sangat pula bergantung pada kondisi sosial mereka.

Phenomena sosial sepanjang pergaulan manusia relative terdapat perbedaan-perbedaan, dimana perbedaan tersebut tampak pada kondisi sosial atau pada realitasnya adanya klasifikasi kedudukan masyarakat yang satu dengan yang lainnya. Kedudukan masyarakat menduduki kelas-kelas sosial tertentu. Kelas-kelas tersebut menjadi warna pola kehidupan masyarkat. Masyarakat yang berada pada posisi kelas yang tinggi maka pola hidupnya pun tidak sama dengan pola hidup masyarakat yang berada pada kelas sosial yang rendah. Ditambah lagi masyarakat yang memilki kelas ekonomi yang tinggi dengan status sosial yang tinggi pula maka pada implikasinya akan memengaruhi keadaan sosial. Sebaliknya masyarakat yang berada pada posisi kelas bawah dengan status sosial yang rendah akan relative tidak akan membawa pengaruh (kekuatan) pada kehidupan sosial masayrakat. Namun tidak semua orang kaya dan berstatus sosial yang tinggi mempunya kekuatan (power/pengaruh) terhadap kehidupan sosial masayarakat.

Pada masyarakat yang belum maju yang ditandai dengan masih melekatnya budaya feudal dan tingkat pendidikan masyarakatnya yang relative rendah, keberadaan power pada umumnya dimiliki oleh orang-orang tertentu yang masih dianggap mempunyai status sosial yang tinggi, seperti pada keturunan bangsawan, orang-orang kaya, kepala suku, dan pemimpin spiritual. Namun pada masyarakat yang sudah maju atau modern keberadaa power tidak mutlak pada masyarakat yang memilki kualifikasi yang ada pada masayarakat feudal melainkan power bisa saja berada pada masyarakat yang berpendidikan tinggi, masayrakat yang bermoral tinggi, masayrakat yang terbukti bertanggung jawab dan memiliki kepekaan sosial.

Posisi masyarakat dengan karakter dan latar belakang yang diklasifikasikan menurut kelas, status serta kepentingan yang beredabeda sangat berpotensi menimbulkan gap pada hubungan sosial kemasyarakatan baik secara individu maupun kelompok. Disinilah titik focus multicultural pada aspek sosial. Dari sanalah perlunya sikap peduli sosial yang dimulai dalam perbedaan kelas dan status sosial, karena perbedaan stratifikasi sosial (termasuk perbedaan kelas dan status sosial) adalah bagian dari multikultural.

Dalam ilmu sisologi multikultural masyarakat pada aspek sosial dipahami dengan istilah stratifikasi sosial.

a. Stratifikasi sosial

Menurut Sorokin stratifikasi sosial adalah suatu pembedaan penduduk ayau masyarakan kedalam kelas-kelas secara bertingkat. Lebih spesifik Robert M. Z. Lawang memberika pengertian, stratifikasi sosial (Pelapisan Sosial) adalah penggolongan untuk pembedaan orang-orang dalam suatu sistem sosial tertentu kedalam lapisan-lapisan hirarkhis menurut dimensi kekuasaan, previlese dan prestise.

Dalam sebuah Negara sedang dilanda berbagai macam krisis yang berkepanjangan 
seperti di Indonesia, timbulnya kesenjangan sosial yang sangat dalam antara kelompok masyarakat yang miskin dan kaya adalah suatu kenyataan yang sulit dihindari. Keadaan seperti ini kemudian menyebabkan timbulnya berbagai kelompok sosial dalam masyarakat itu sendiri. Kelompok sosial ini merupakan salah satu bentuk dan bagian dari stratifikasi sosial.

Stratifikasi sosial itu sendiri, sebenarnya merupakan akibat ketidaksamaan posisi dan tempat secara sosial di dalam masyarakat yang berbentuk pengkategorian yang berbeda-beda, sehingga kesempatan untuk mendpatkan akses tertentu seperti sosial menjadi berbeda. Stratifikasi soial adalah sebuah fenomena sosial. Stratifikasi sosial bukan merupakan karakter yang dibawa manusia sejak lahir atau disebabkan oleh kekuatan supranatural yang dating dari luar kemampua manusia. Stratifikasi sosial merupakan akibat dari perbuatan manusia yang dilakukan sekarang atau pada masa lalu.

Penggolongan untuk pembedaan artinya setiap induvidu menggolongkan dirinya sebagai orang yang termasuk dalam suatu lapisan tertentu (menganggap dirinya lebih rendah atau lebih tinggi daripada orang lain) untuk digolongkan kedalam lapisan tertentu. Pelapisan sosial merupakan proses menempatkan diri dalam suatu lapisan (subyektif) untuk penempatan orang kedalam lapisan tertentu. Contoh Subyektif

1) Sekelompok orang karena faktor tertentu (biasanya status) tidak mau disamakan dengan sekelompok yang lain.

2) Sekelompok orang yang lebih kaya kadang merasa risih bergaul dengan yang miskin

Contoh Obyektif Sekolompok orang merasa minder ( factor tertentu) apabila bergaul dengan orang kelasnya lebih diatasnya.

Webber menjelaskan bahwa di dalam stratifikasi sosial terdapat tiga unsur pokok yaitu: kelas (class), status (status), dan pengaruh (power).

\section{1) Kelas (class)}

Kelas adalah ranking sosial dalam masyarakat yang diukur berdasarkan faktorfaktor dan nilai-nilai ekonomi. Berkaitan dengan bahasan ini, Indonesia sendiri kelas sosial dibagi menjadi tiga kelompok utama yaitu:

a) Kelompok masyarakat kelas bawah yaitu golongan masyarakat yang tidsk mempunyai penghasilan tetap atau mereka yang berpenghasilan tetap tetapi tidak dpat digunakan untuk mencukupi kebutuhan pokoknya setiap hari. Kelompok ini biasanya mempunyai kesempatan dan akses yang sangat kecil untuk meraih kehidupan sosial, ekonomi, politik dan pendidikan yang lebih baik.

b) Kelompok masyarakat kelas menengah. Golongan kelas menengah yaitu kelompok masyarakat yang mempunyai penghasilan tetap yang dapat digunakan untuk mencukupi kebutuhan pokok sehari-hari. Kelompok kelas menengah mempunyai kesempatan dan akses yang cukup untuk meraih kehidupan sosial, ekonomi, politik dan pendidikan yang lebih baik.

c) Kelas atas adalah golongan masyarakat yang tidak hanya mempunyai penghasilan tetap setiap bulannya, akan tetapi juga mempunyai sumber penghasilan yang lebih dari satu. Tentunya penghasilan masyarakat yang ada pada kelas ini tidak cukup untuk kebutuhan hidup sehari-hari saja, tetapi lebih dari itu. Mereka dapat memenuhi kebutuhan-kebutuhan lainnya.

2) Status

Status adalah ranking sosial yang didasarkan pada prestos seperti gengsi, maupun martabat dan wibawa di dalam kehidupan masyarakat. Status ini biasanya didasarkan pada tiga kategori seperti pekerjaan, idelogi dan keturunan.

3) Power

Merupakan ranking sosial yang diukur dari sejauhmana seseorang mampu mempengaruhi orang lain untk melakukan sesuatu seperti yang dia inginkan. dalam masyarakat yang masih lekat dengan budaya feudal dengan tingkat pendidikan yang masih rendah, keberadaan power pada umunya ada pada orang-orang tertentu yang 
masih dianggap mempunyai status sosial yang tinggi seperti para keturunan bangsawan, orang-orang kaya, kepala suku dan pemimpin spiritual. Sedangkan pada masyarakat yang sudah maju, power tidak hanya ada pada orang-orang kaya, keturunan bagsawan, kepala suku atau pemimpin spiritual. Akan tetapi juga dapat ditemukan pada orang-ornag yang berpendidikan, bermoral dan etika tinggi, dan pada orang-orang yang terbukti mampunyai rasa tanggung jawab sosial yang tinggi.

\section{Permasalahan Sosial Sebagai Konseluensi Stratifikasi Dan Diferensiasi Sosial}

1. Konflik sosial

Harus diakui bahwa gesekan-gesekan horizontal yang terjadi di masyarakat merupakan akibat dari tidak adanya kepercayaan pubik terhadap institusi pelayanan masyarakat di berbagai bidang, terutama hukum dan ekonomi sehingga masyarakat cenderung mencari cara-cara dan alternatif lain yang dinilai singkat untuk mengatasi masalah yang sedang dihadapinya. Dari berbagai kasus kerusuhan yang timbul bila kita cermati ini ditimbulkan oleh perselisihan-perselisihan kecil yang terjadi di masyarakat yang penyelesaiannya tidak pernah tuntas dan tidak pernah memberikan keadilan yang berpihak pada publik (walaupun kita tahu bahwa rasa keadilan itu bersifat subjektif), sehingga publik dalam hal ini masyarakat selalu menyelesaikan konflik-konflik tersebut melalui sudut pandang mereka. Sudut pandang inilah uang sering dijadikan masyarakat sebagian masyarakat sebagai suatu pembenaran universal yang timbuh dari opini dan latar belakang budaya kontemporer yang tumbuh di masyarakat. Isusiu yang berkembang dalam kerusuhan sering kali menjebak dan cenderung melebar dari permasalahan sebenarnya, oleh karena itu dibutuhkannya lembaga yang benar-benar bisa dipercaya dalam menyelesaikan setiap konflik yang terjadi dengan melibatkan seluruh unsur yang ada di masyarakat mulai dari tokoh masyarakat, tokoh budaya, pemimpin non formal masyarkat dan baru pada unsur terakhir bisa dilibatkan pihak kepolisian.

Plurarisme pada masyarakat indonesia sangat mudah untuk dibenturkan dan di pecah belah terutama terhadap isu keagamaan dan kesukuan. Dalam beberapa kejadiian ini menjadi konflik yang sangat rumit yang mingkin penyelesaiannya cenderung berlarutberlarut karena adanya ego dari suatu kelompok kepentingan (yang mungkin mendapatkan keuntungan dari adanya kerusuhan). Arus informasi (dalam hal ini pemberitaan media) kerap kali di tuding menjadi suatu pemicu semakin meluasnya suatu kerusuhan, terutama dari pemberitaan media yang terlalu propokatif dalam menempatkan judul beritanya seakan mengajak para pembacanya terlibat lebih jauh. Pemberitaan berimbang dan memberikan fakta aktual yang layak jadi informasi publik memang harus, tetapi jangan sampai meninggalkan latar belakang sosiologis dari masyarakat juga karena itu akan berdampak buruk bagi konflik tersebut. Seakan ada dualisme kepentingan yang dijalankan media melalui pemberitaannya, yaitu tentang memberikan informasi dan menggiring opini publik pada kepentingan penguasa. Betapa kuaatnya peran media ini kadang tidak pernah disadari oleh masyarakat kelas bawah, mereka seakan selalu menjadi pihak yang dinilai pelanggar atau pemicu dari kerusuhan. Walaupun harus kita akui bahwa banyak diantara yang terlibat kerusuhan itu tidak mengetahui akar masalah yang sebenarnya dan dieksploitasi sedemikian rupa. Mungkin mereka terbentuk dari kerumunan yang yang baik itu secara langsung atau pun tidak terbawa arus. Karena memang kerusuhan itu masalah yang kompleks.

2. Kesenjangan dalam kesetaraan dan keadilan

Salah satu ciri masyarakat multikultural yaitu adanya keinginan suatu kelompok tertentu untuk menguasai peran atau misi dominasi terhadap kelompok masyarakat lainnya. Keinginan tersebut kemudian dimunculkan melalui gerakan-gerakan yang secara tidak 
langsung dapat menggerus hak dan kepentingan kelompok-kelompok masyarakat lain yang tergolong minoritas.

Keberadaan kelompok minoritas selalu dalam kaitan dan pertentangannya dengan kelompok dominan, yaitu mereka yang menikmati status sosial tinggi dan sejumlah keistimewaan yang banyak. Mereka ini mengembangkan seperangkat prasangka terhadap golongan minoritas yang ada dalam masyarakatnya. Perasangka-perasangka yang berkembang di masyarakat mayoritas kemudian memunculkan klaim bahwa sebagaian besar akses sumber daya yang ada merupakan hak mereka, dan disertai adanya ketakutan bahwa mereka yang tergolong minoritas dan rendah derajadnya itu akan mengambil sumberdayasumberdaya tersebut.

\section{Pendidikan multikultural sebagai langkah prefentiv terhadap permasalahan sosial}

Sebagai strategi dari integrasi sosial maka multikultural mengakui dan menghormati keanekaregaman. Hal ini membawa implikasi dalam bersikap bahwa realitas sosial yang sangat polimorfik atau majemuk tak akan menjadi kendala dalam membangun pola hubungan sosial antara individu yang penuh toleransi. Bahkan akan tumbuh sikap yang dapat menerima kenyataan untuk hidup berdampingan secara damai satu sama lain dengan perbedaan-perbeddaan yang melekat pada tiap entitias sosial. Sehingga di tegaskan bahwa multikultural merupakan suatu konsep yang ingin membawa masyarakat sosial dalam kerukunan dan perdamaian tanpa ada konflik dan kekerasan meskipun didalamnya terdapat kompleksitas perbedaan.

Eksistensi pendidikan multicultural merupakan sutau upaya untuk membentuk masyarakat yang multikultural. Masyarakat multikultural adalah masyarakat yang terdiri dari beberapa kebudayaan. Dengan multikultural diharapkan mampu mendukung kebudayaan saling menghargai satu sama lain. Jadi masyarakt sosial yang menganut multukulturalisme yaitu masyarakat yang mempunyai pemikiran bahwa berbagai budaya yang terjadi dimasyarakat memiliki keududukan yang sederajat.

Pada prinsipnya multicultural mengajarkan kepada kita untuk mengakui berbagai potensi dan legitimasi keragaman dan perbedaan sosial tiap kelompok. Berangkat dari prinsip demikian maka individu maupun kelompok dari berbagai etnic dalam pandangan ini, biasa bergabung dalam masyarakat, terlihat dalam societal cohesion (hubungan masyarakat) tanpa harus kehilangan identitas etnis dan budaya mereka, sekaligus tetap memperoleh hak-hak mereka untuk berpartisipasi penuh dalam berbagai bidang kegiatan masyarakat atau kegiatan sosial. Sehingga keberagaman sosial yang ada dimasyarakat bisa memberikan sumbangan bagi semua orang.

Paradigma multicultural dalam konteks sosial memberi pelajaran kepada kita untuk memiliki apresiasi dan respect terhadap lapisan masyarakat. Atas dasar ini maka penerapan multicultural menuntu kesadaran dari masingmasing lapisan masyarakat untuk saling mengakui dan menghormati keanekaragaman identitias setiap masyarakatnya yang dibalut kerukunan dan perdamaian. Dengan kesadaran dan kepekaan terhadap kemajemukan masyarakat akan bisa mereduksi berbagai potensi yang dapat memicu konflik sosial.

Permasalahan sosial dapat terjadi di masyarakat sebagai akibat dari adanya interaksi sosial. Masalah itu akan lebuh menonjol laghi di masyarakat yang bersifat majemuk seperti Indonesia. Setiap orang atau kelompok dalam menghadapi permaslaahan sosial selalu me; lihat dari system nilai yang berlaku pada kelompoknya. Oleh karena masyarakat Indonesia merupakan masyarakat majemauk terdiri dari bermacam-macam kebudayaan, seperti: kebudayaan jawa, batak aceh, sunda, bali, ambon, dll. Sedangkan system nilai merupakan bagian dari kebudayaan. Maka betapa kompleksnya masalah-maslah sosial yang timbul di masyarakat Indonesia.

Dunia pendidikan dimasa depan memang dituntut lebih dekat lagi dengan realitas dan 
permasalahan hidup yang tengah menghimpit masyarakat. Ungkapan school is mirror society seyogyanya benar-benar mewarnai proses pendidikan yang berlangsung. Sebagai konsekuensinya lembaga pendidikan harus ikut berperan aktif dalam memecahkan problem sosial. Komitmen terhadap pemecahan problem sosial seperti itu seharusnya menjadi bagian dari visi dan misi dunia pendidikan nasional. Bahkan lembaga pendidikan nasional semakin dituntut untuk lebih melipat ganddakan komitmen sosiologisnya, mengingat kompleksitas yang tengah dihadapi Indonesia.

Dengan multikulturalisme menumbuhkan kesadaran berfikir obyektif dari masyarakat dalam melihat seseorang dengan segala macam status sosial dan perbedaan kelas (stratifiksi sosial) yang melekat pada dirinya. Kekayaan atau keningratan adalah bukan ukuran satusatunya bagi seseorang untuk mendapatkan penghormatan, penghargaan, dan prestos (status sosial yang tinggi) dalam kehidupan masyarakat. Masyarakat akan lebih melihat kepribadian, kemampuan dan tanggung jawab sosial yang positif yang ada pada seseorang terhadap diri sendiri, keluarga maupun lingkungan disekitarnya.

Selain itu dengan multikulturalisme seseorang diharapkan bisa beranggapan bahwa tidak semua orang kaya dan orang berstatus sosial tinggi mempunyai kekuatan mempengaruhi orang lain untuk melakukan sesuatu. Namun demikian, orang yang mempunyai status dan posisi kelas sosial yang tinggi mempunyai kesempatan yang lebih besar untuk mempengaruhi orang lain ${ }^{1}$.

\section{DAFTAR PUSTAKA}

Alfian. 1986. Transformasi sosial budaya dalam pembangunan. Jakarta. UI-press

Choirul Mahfud. 2006. Pendidikan Multikultural. Yogyakarta : Pustaka Pelajar.
Fromm, Erich. 2000. Akar Kekerasan: Analisis Sosio-psikologis atas Watak Manusia. Yogyakarta: Pustaka Pelajar.

H.A.R. Tilaar, 2004, Multikulturalisme, Jakarta: PT. Gramedia

Muhammad Ali, Teologi Plurailsmultikulturalis, Menghargai Kemajemukan Menjalin Kebersamaan (Jakarta: Kompas, 2003)

Nurul Hidayah. Artikel "Masyarakat Multikultural". staffnew.uny.ac.id/upload/132309997/ MASYARAKAT++MULTIKULTUR AL.pdf

Yakin, Ainul, 2005, Pendidikan Multikultural, Yogayakarta: Pilar Media

Zubaedi. 2005. Pendidikan berbasis masyarakat. Yogyakarta. Pustaka Pelajar

\footnotetext{
${ }^{1}$ Yakin, Ainul, 2005, Pendidikan Multikultural,

Yogayakarta: Pilar Media, h. 153
}

Jurnal Pendidikan Mandala 